\title{
Influence of Silicon Forms on Nutrients Accumulation and Grain Yield of Wheat Under Water Deficit Conditions
}

\author{
Emad M. M. Salem ${ }^{1} \cdot$ Mohammed K. M. Kenawey $^{1} \cdot$ Hani Saber Saudy ${ }^{2}$ (D) Manal Mubarak ${ }^{3}$
}

Received: 15 October 2021 / Accepted: 25 January 2022 / Published online: 17 February 2022

(c) The Author(s) 2022

\begin{abstract}
Wheat productivity is severely hampered by drought, owing to its negative impacts on crop growth and development. For obtaining better yield, the impacts of drought should be ameliorated. Therefore, the current study scrutinizes the potential of different silicon ( $\mathrm{Si}$ ) forms to minify the drought-associated reduction in yield and the changes in nutrients accumulation. In a strip plots design based on randomized complete block arrangement using 3 replicates, two field experiments were carried out in 2019/20 and 2020/21 seasons. Three silicon (Si) forms (potassium silicate, calcium silicate, and aluminum silicate), in addition to the control (tap water) were sprayed. Also, three irrigation regimes were applied as ratio of crop evapotranspiration (60, 80 and 100\%, denoted Irr60, Irr80 and Irr100, respectively). Findings clarified that application of aluminum silicate in both seasons, in addition to calcium silicate in the second season recorded the maximum accumulation of $\mathrm{Si}$ in wheat plants. Supplying wheat plants with different forms of Si reduced zinc $(\mathrm{Zn})$ and manganese $(\mathrm{Mn})$ and increased Si compared to the control (no Si application). Irr100 possessed increase in accumulation of Si in plant tissues greater than Irr80 or Irr60. Significant increases in all agronomic traits of wheat were obtained owing to spraying any Si form compared to the control. The differences between potassium silicate, calcium silicate, and aluminum silicate were not significant in flag leaf greenness (SPAD value), grains weight spike ${ }^{-1}$, weight of 1000 grains, and grain yield ha ${ }^{-1}$ in 2020/21 season. Irr100 was the effective treatment for enhancing SPAD value, spike length, grains weight spike ${ }^{-1}$, weight of 1000 grains, and grain yield ha ${ }^{-1}$. When irrigation water was reduced by $20 \%$ (Irr80), the lowest reduction in grain yield was obtained with potassium silicate compared to other forms of $\mathrm{Si}$. It could be concluded that since lower accumulation of $\mathrm{Si}$ in plant tissues under water deficit than well-watered was recorded, the spraying of Si is great of importance to be applied under drought stress.
\end{abstract}

Keywords Nutrient uptake $\cdot$ Oxidative stress $\cdot$ Silicate compounds $\cdot$ Water requirement $\cdot$ Wheat yield potential

Hani Saber Saudy

hani_saudy@agr.asu.edu.eg

1 Department of Plant Production, Ecology and Dry Land Agriculture Division, Desert Research Center, El-Matareya, 11753 Cairo, Egypt
2 Agronomy Department, Faculty of Agriculture, Ain Shams University, Hadayek Shoubra 11241, 68, Cairo, Egypt

3 Soil \& Water Department, Faculty of Agriculture, Ain Shams University, Hadayek Shoubra 11241, 68, Cairo, Egypt 


\section{Einfluss von Siliziumformen auf die Nährstoffakkumulation und den Kornertrag von Weizen unter Wassermangelbedingungen}

\section{Zusammenfassung}

Die Weizenproduktivität wird aufgrund der nachteiligen Auswirkungen auf das Wachstum und die Entwicklung der Pflanzen durch Dürre stark eingeschränkt. Um einen besseren Ertrag zu erzielen, sollten die Auswirkungen von Trockenheit gemildert werden. Daher untersucht die aktuelle Studie das Potenzial verschiedener Silizium ( $\mathrm{Si}$ )-Formen, die dürrebedingte Ertragsminderung und die Veränderungen der Nährstoffakkumulation zu minimieren. In einem Strip-Plot-Design auf Basis eines randomisierten vollständigen Blockdesigns mit 3 Wiederholungen wurden in den Saisons 2019/20 und 2020/21 zwei Feldversuche durchgeführt. Drei Si-Formen (Kaliumsilikat, Kalziumsilikat und Aluminiumsilikat) wurden zusätzlich zur Kontrolle (Leitungswasser) gesprüht. Außerdem wurden drei Bewässerungsregime im Verhältnis zur Evapotranspiration der Pflanzen angewandt (60, 80 und 100\%, bezeichnet als Irr60, Irr80 bzw. Irr100). Die Ergebnisse verdeutlichten, dass die Anwendung von Aluminiumsilikat in beiden Saisons zusätzlich zu Kalziumsilikat in der zweiten Saison die maximale Anreicherung von Si in Weizenpflanzen verzeichnete. Die Versorgung von Weizenpflanzen mit verschiedenen Si-Formen reduzierte $\mathrm{Zn}$ und $\mathrm{Mn}$ und erhöhte Si im Vergleich zur Kontrolle (keine Si-Anwendung). Bei Irr100 war die Si-Akkumulation in den Pflanzengeweben stärker als bei Irr80 oder Irr60. Bei allen agronomischen Merkmalen von Weizen wurden im Vergleich zur Kontrolle signifikante Steigerungen durch das Sprühen jeglicher Si-Form erzielt. Die Unterschiede zwischen Kaliumsilikat, Kalziumsilikat und Aluminiumsilikat waren in der Saison 2020/21 bzgl. des SPAD-Werts, dem Korngewicht pro Ähre, dem 1000-Korn-Gewicht und dem Kornertrag pro ha nicht signifikant. Irr100 war die wirksamste Behandlung zur Verbesserung des SPAD-Werts, der Ährenlänge, des Korngewichts pro Ähre, des 1000-Korn-Gewichts und des Kornertrags pro ha. Bei einer Reduzierung des Bewässerungswassers um 20\% (Irr80) wurde mit Kaliumsilikat im Vergleich zu anderen Si-Formen die geringste Verringerung des Kornertrags erzielt. Da eine geringere Anreicherung von Si im Pflanzengewebe bei Wasserdefizit als bei guter Bewässerung festgestellt wurde, könnte man zu dem Schluss kommen, dass das Besprühen mit Si bei Trockenstress von großer Bedeutung ist.

Schlüsselwörter Nährstoffaufnahme · Oxidativer Stress · Silikatverbindungen · Wasserbedarf · Weizenertragspotenzial

\section{Introduction}

Wheat (Triticum aestivum L.) occupies a pivotal position among cereals around the world and contributes a significant part of daily calories and protein intake (Kizilgeci et al. 2021). Beneficial components to human health such as proteins, minerals, vitamins, phytochemicals, and dietary fibers could be provided from wheat (Shewry and Hey 2015). Owing to its contribution as the major staple food crop universally, wheat is ranked at the first position among cereals (Iqbal et al. 2021). Nevertheless, yield potential of wheat is limited due to climate change effects, especially abiotic stresses, including heat, salinity, and drought (Yadav et al. 2020).

It is well known that water is one of the most significant factors affecting growth and development of crop plants. It has been proved the critical role of water in physiological processes especially photosynthesis and nutrient uptake. Accordingly, deficiency or unavailability of water will cause imbalance in all plant biological pathways. In this respect, drought as an environmental factor mutates the pathway stability of water and nutrients to become out of balance (Meena et al. 2017; Saudy and El-Metwally 2019), hence, reductions in plant growth and yield owing to low water supply were obtained (El-Metwally et al. 2022; Saudy et al.
2021; Abd-Elrahman et al. 2022). While, in arid and semiarid conditions, farmers are forced to irrigate the crops with less water than required, due to lack of irrigation water, although the shortage in yield is realized. In this concern, applying practices that mitigate the adverse effect of water deficit is a crucial action. In several plant species, as wheat, the potentiality of silicon $(\mathrm{Si})$ to reinforce the environmental stresses tolerance was obtained (Rodrigues et al. 2015). Si could enhance plant growth under normal and stress conditions (Saudy and Mubarak 2015). The induction of plant resistance by Si to stress might be attributed to formation of phytoliths and polymerization of insoluble $\mathrm{Si}$ in cell walls and around the vascular bundle, reducing water loss, by controlling transpiration (Mecfel et al. 2007). Also, Si activates the antioxidant mechanisms to quench the reactive oxygen species (ROS) production, hence, reduce lipid peroxidation (Ye et al. 2013; Rodrigues et al. 2015; AbdelHaliem et al. 2017). Application of Si increased water and osmotic potential in roots and leaves as well as alleviated water stress partially (Ming et al. 2012). Since Si has a vital role in enhancing growth and yield (Salim 2014), in the future, its application will become a sustainable strategy and mitigate the adverse impacts under abiotic stress (Etesami and Ryong Jeong 2018). 
The effect of cation associated $\mathrm{Si}$ in the used compounds should not be neglected. There are several forms of Si could be used as fertilizers like aluminum silicate, calcium silicate and potassium silicate. Although potassium silicate has received great attentions, very little information is available about aluminum silicate and calcium silicate. The harmful impacts of low water supply were reduced by application of potassium silicate (Abu-Muriefah 2015).

The most favorite form of $\mathrm{Si}$ for plant growth, especially under stresses, is still unclear. In the current work we hypothesized that the different forms of Si supply have different impacts toward the plant response to water stress. Thus, the aim was to compare the potentialities of aluminum, calcium, and potassium silicates for alleviating the water deficit impacts on wheat.

\section{Materials and Methods}

\section{Study area Description}

At Maryout experimental station, Desert Research Centre (latitude $31^{\circ} 00^{\prime} 21^{\prime \prime} \mathrm{N}$, longitude $29^{\circ} 47^{\prime} 26^{\prime \prime} \mathrm{E}$ ), adjacent to the Mediterranean coast, Alexandria, two field experiments were carried out in winter seasons of 2019/20 and $2020 / 21$. The soil was a calcareous of sandy loam texture and its properties and water status are presented in Table 1. According to soil taxonomy (IUSS Working Group WRB 2015), the soil is order Entisols and suborder psamments. As an average of the two seasons, the mean values of daily

Table 1 Initial physico-chemical traits and water status of soil at the experimental research station of Maryout, Egypt

\begin{tabular}{lll}
\hline Parameter & Unit & Value \\
\hline Mechanical analysis & $\%$ & 92.0 \\
Sand & $\%$ & 2.10 \\
Silt & $\%$ & 5.90 \\
Clay & & \\
Chemical analysis & - & 8.10 \\
pH (1:2.5) & $\mathrm{dS} \mathrm{m}{ }^{-1}$ & 0.72 \\
Electrical conductivity $(\mathrm{EC})$ & $\mathrm{Meq} \mathrm{L}$ & \\
Calcium cations $\left(\mathrm{Ca}^{+2}\right)$ & $\mathrm{Meq} \mathrm{L}$ & 1.91 \\
Magnesium cations $\left(\mathrm{Mg}^{+2}\right)$ & $\mathrm{Meq} \mathrm{L}$ & 0.93 \\
Sodium cations $\left(\mathrm{Na}^{+}\right)$ & $\mathrm{Meq} \mathrm{L}$ & 0.29 \\
Potassium cations $\left(\mathrm{K}^{+}\right)$ & $\mathrm{Meq} \mathrm{L}$ & 3.01 \\
Chloride anions $\left(\mathrm{Cl}^{-}\right)$ & $\mathrm{Meq} \mathrm{L}$ & 1.33 \\
Bicarbonate anions $\left(\mathrm{HCO}_{3}^{-1}\right)$ & $\mathrm{Meq} \mathrm{L}$ & 3.40 \\
Sulphate anions $\left(\mathrm{SO}_{4}^{-1}\right)$ & $\%$ & 2.23 \\
Calcium carbonate $\left(\mathrm{CaCO}_{3}\right)$ & & 24.12 \\
Water status & $\%$ & \\
Saturation percentage & $\%$ & 29.52 \\
Field capacity & & 20.20 \\
Wilting point & & 9.21 \\
\hline
\end{tabular}

air temperature, wind speed, relative humidity, precipitation, and solar radiation were $17.3^{\circ} \mathrm{C}, 2.73 \mathrm{~m} \mathrm{sec}^{-1}, 60.4 \%$, $0.57 \mathrm{~mm}$, and $16.7 \mathrm{MJ} \mathrm{m}^{-2} \mathrm{day}^{-1}$, respectively. The preceding cultivated crop was sorghum (Sorghum bicolar L.) in both seasons.

\section{Experimental Treatments}

The experiment was implemented in a strip plots design based on randomized complete block arrangement using 3 replicates. In the vertical plots, three silicon ( $\mathrm{Si}$ ) forms (potassium silicate, calcium silicate, and aluminum silicate each of them containing $0.05 \% \mathrm{Si}$ ), in addition to the control (tap water) were sprayed. While, three irrigation regimes, were applied as ratio of crop evapotranspiration (60, 80 and $100 \%$, denoted Irr60, Irr80 and Irr100, respectively), occupied the horizontal plots. Silicon treatments were applied as foliar applications twice, 65 and 80 days after sowing (DAS), at a rate of $500 \mathrm{ml} \mathrm{L}^{-1}$. Irrigation water was applied equally to all irrigation treatments to increase the soil moisture up to field capacity until the 4-6 leaf growth stage (25 DAS); then, the irrigation treatments were started. Based on the meteorological data of the study area, reference evapotranspiration was calculated using FAO 56-Penman-Monteith method (formula 1) given by Allen et al. (1998) as follow:

$\mathrm{ET}_{o}=\frac{0.408 \Delta\left(\mathrm{R}_{n}-\mathrm{G}\right)+\gamma[900 /(\mathrm{T}+273)] \mathrm{U}_{2}\left(\mathrm{e}_{s}-\mathrm{e}_{a}\right)}{\Delta+\gamma\left(1+0.34 \mathrm{U}_{2}\right)}$

where: $\mathrm{ET}_{\mathrm{o}}$ is reference evapotranspiration $\left(\mathrm{mm} \mathrm{day}^{-1}\right), \mathrm{R}_{\mathrm{n}}$ is net radiation at the crop surface $\left(\mathrm{MJ} \mathrm{m}^{-2}\right.$ day $\left.^{-1}\right), \mathrm{G}$ is soil heat flux density $\left(\mathrm{MJ} \mathrm{m}^{-2}\right.$ day $\left.^{-1}\right), \mathrm{T}$ is mean daily air temperature at $2 \mathrm{~m}$ height $\left({ }^{\circ} \mathrm{C}\right), \mathrm{U}_{2}$ is wind speed at $2 \mathrm{~m}$ height $\left(\mathrm{m} \mathrm{sec}^{-1}\right), \mathrm{e}_{\mathrm{s}}$ is saturation vapor pressure $(\mathrm{kPa}), \mathrm{e}_{\mathrm{a}}$ is actual vapor pressure $(\mathrm{kPa}), \mathrm{e}_{\mathrm{s}}-\mathrm{e}_{\mathrm{a}}$ is saturation vapor pressure deficit $(\mathrm{kPa}), \Delta$ is slope of vapor pressure curve $(\mathrm{kPa}$ $\left.{ }^{\circ} \mathrm{C}^{-1}\right)$ and $\gamma$ is psychrometric constant $\left(\mathrm{kPa}^{\circ} \mathrm{C}^{-1}\right)$.

Using the formula 2 (Allen et al. 1998), wheat crop evapotranspiration was estimated

$\mathrm{ETc}=\mathrm{Kc} \times \mathrm{ETo}$

where $\mathrm{ET}_{\mathrm{c}}$ is daily crop evapotranspiration $(\mathrm{mm}) ; \mathrm{K}_{\mathrm{c}}$ is daily crop coefficient; $\mathrm{ET}_{\mathrm{o}}$ is grass reference evapotranspiration (mm).

Accordingly, the irrigation water amount $\left(\mathrm{m}^{3} \mathrm{ha}^{-1}\right)$ received by wheat plants was approximately 2519.2 and 2838.9 with Irr60; 3325.6 and 3751.8 with Irr80 as well as 4132.0 and 4664.8 with Irr100 treatments in the first and second seasons, respectively. 
Plants were irrigated through gated pipe irrigation system and the application irrigation efficiency was $80 \%$. The PVC gated pipes were installed in irrigation channel against the upper end of the furrows, which convey the water based on the required flow rate (one gate per furrow). The temporary dam was used to keep a constant hydraulic head, to realize adequately inflow rate during irrigation events. The inflow rate was $901 \mathrm{pm}$ furrow $^{-1}$, which predetermined according to the technique of Merriam et al. (1983). The amount of water applied was estimated by a flow meter installed on the delivery line of the irrigation system. Soil surface slope was $0.20 \%$. Irrigation cutoff was at $90 \%$ of furrow length and runoff was negligible, which the furrows were closedends. The water amount applied during each irrigation event was appropriate to the crop's growth stage as described by Dorrenbos and Pruitt (1977). Soil water content was measured by gravimetric method (Merriam et al. 1983) before and after irrigation events along furrow length to a depth of $1.0 \mathrm{~m}$ in depth increments of $0.2 \mathrm{~m}$ to evaluate the soil moisture distribution and irrigation performance.

The volume of water applied for each plot was calculated as follow by formula 3 :

$\mathrm{Q}=\mathrm{q} \times \mathrm{T} \times n$

where: $\mathrm{Q}$ is water volume $\left(\mathrm{L} \mathrm{plot}^{-1}\right), \mathrm{q}$ is irrigation water inflow rate furrow ${ }^{-1}\left(\mathrm{~L} \mathrm{minute}^{-1}\right), \mathrm{T}$ is total irrigation time furrow ${ }^{-1} \mathrm{~min}^{-1}$ and $n$ is number of furrows per plot ${ }^{-1}$.

\section{Crop Management}

With land preparation, the ordinary single super phosphate $\left(15.5 \% \mathrm{P}_{2} \mathrm{O}_{5}\right)$, at a rate of $240 \mathrm{~kg} \mathrm{ha}^{-1}$, and gypsum, as a soil conditioner, at a rate of $2.4 \mathrm{tha}^{-1}$, were incorporated. Soil divided into strips which separated by boarders $(2.1 \mathrm{~m}$ land spacings) to minimize water superposition among irrigation treatments. The experimental unit size was $10.5 \mathrm{~m}^{2}$ $(3 \mathrm{~m} \times 3.5 \mathrm{~m})$. On 19 November in 2019 and 2 December in 2020, wheat grains (cv. Giza-171) were planted in lines, $10 \mathrm{~cm}$ distance, at a rate of $150 \mathrm{~kg}$ grains ha ${ }^{-1}$. At 30 DAS, ammonium nitrates fertilizer $(33.5 \% \mathrm{~N})$ at a rate of $450 \mathrm{~kg}$ $\mathrm{ha}^{-1}$ was applied.

\section{Data Record}

\section{Plant Analysis}

Representative plant samples were obtained at 105 DAS for carrying out the chemical analysis at Central Laboratory, Soil and Water Unit, Faculty of Agriculture, Ain Shams University. Total nitrogen $(\mathrm{N})$ was determined by micro Kjeldahl using $5 \%$ boric acid and $40 \% \mathrm{NaOH}$ as described by Chapman and Pratt (1961). Total phospho- rus (P) was estimated using Spectrophotometer according to the method described by Watanabe and Olsen (1965). Total potassium (K) was measured using Flame photometer (Chapman and Pratt 1961). Iron (Fe), zinc (Zn), manganese $(\mathrm{Mn})$ and silicon $(\mathrm{Si})$ were determined using ICP Mass Spectrometry (Benton 2001).

\section{Crop Traits}

Flag leaf greenness (SPAD value) was measured at 105 DAS by chlorophyll meter (SPAD-502Plus) according to Süß et al. (2015).

Wheat plants were harvested on 15 and 21 April in 2020 and 2021 seasons, respectively. Ten plants were randomly chosen from each plot to measure plant height, spike length, grains weight spike ${ }^{-1}$ and weight of 1000 grains. Furthermore, whole plants of each plot were collected to estimate straw and grain yields ha ${ }^{-1}$.

\section{Statistical Analysis}

A two-way analysis of variance (ANOVA) for the data of the two seasons was undertaken (Casella 2008), using Costat software program, Version 6.303 (2004). Based on Duncan's multiple range test, means separation were performed only when the F-test indicated significant $(p<0.05)$ differences among the treatments.

\section{Results}

\section{Plant Analysis}

Analysis of variance proved that neither Si form nor irrigation had significant effects on all estimated macronutrients in wheat in both growing seasons of 2019/20 and 2020/21 (Table 2). While, except for Fe, the other studied micronutrients affected significantly by $\mathrm{Si}$ form and irrigation (Table 3). Supplying wheat plants with different forms of $\mathrm{Si}$ reduced $\mathrm{Zn}$ and $\mathrm{Mn}$ and increased $\mathrm{Si}$ compared to the control (no Si application) in both seasons. However, potassium silicate in the first season and aluminum silicate in the second season showed similar Mn values as the control. Moreover, application of aluminum silicate in both seasons, in addition to calcium silicate in the second season recorded the maximum values of $\mathrm{Si}$.

Except for Mn in 2020/21, all micronutrients responded significantly to irrigation regimes. Under Irr60, higher concentrations of $\mathrm{Zn}$ (in both seasons) and $\mathrm{Mn}$ (in the first season) were obtained (Table 3). On the contrary, the maximum concentration of Si was observed with Irr100 (in both seasons), in addition to Irr80 (in the second season). 
Table 2 Influence of silicon form and irrigation regime on nitrogen (N), phosphorus (P), and potassium (K) content in wheat plants in 2019/20 (S1) and 2020/21 (S2) seasons

\begin{tabular}{|c|c|c|c|c|c|c|}
\hline \multirow[t]{2}{*}{ Variable } & \multicolumn{2}{|l|}{$\mathrm{N} \%$} & \multicolumn{2}{|l|}{$\mathrm{P} \%$} & \multicolumn{2}{|l|}{$\mathrm{K} \%$} \\
\hline & $\overline{S 1}$ & S2 & S1 & S2 & $\overline{S 1}$ & $\mathrm{~S} 2$ \\
\hline \multicolumn{7}{|l|}{ Silicon form } \\
\hline Potassium silicate & $1.87 \mathrm{a}$ & $2.23 \mathrm{a}$ & $0.28 \mathrm{a}$ & $0.28 \mathrm{a}$ & $2.12 \mathrm{a}$ & $1.80 \mathrm{a}$ \\
\hline Calcium silicate & $1.65 \mathrm{a}$ & $1.87 \mathrm{a}$ & $0.26 \mathrm{a}$ & $0.29 \mathrm{a}$ & $2.22 \mathrm{a}$ & $1.87 \mathrm{a}$ \\
\hline Aluminum silicate & $1.76 \mathrm{a}$ & $2.23 \mathrm{a}$ & $0.25 \mathrm{a}$ & $0.33 \mathrm{a}$ & $1.81 \mathrm{a}$ & $2.01 \mathrm{a}$ \\
\hline Control & $1.96 \mathrm{a}$ & $1.78 \mathrm{a}$ & $0.27 \mathrm{a}$ & $0.28 \mathrm{a}$ & $2.21 \mathrm{a}$ & $1.86 \mathrm{a}$ \\
\hline \multicolumn{7}{|l|}{ Irrigation regime } \\
\hline Irr60 & $1.80 \mathrm{a}$ & $2.25 \mathrm{a}$ & $0.27 \mathrm{a}$ & $0.28 \mathrm{a}$ & $1.95 \mathrm{a}$ & $1.88 \mathrm{a}$ \\
\hline Irr80 & $1.86 \mathrm{a}$ & $1.89 \mathrm{a}$ & $0.26 \mathrm{a}$ & $0.29 \mathrm{a}$ & $1.94 \mathrm{a}$ & $1.79 \mathrm{a}$ \\
\hline Irr100 & $1.76 \mathrm{a}$ & $1.93 \mathrm{a}$ & $0.27 \mathrm{a}$ & $0.31 \mathrm{a}$ & $2.38 \mathrm{a}$ & $1.98 \mathrm{a}$ \\
\hline
\end{tabular}

Irr60, Irr80 and Irr100: irrigation at 60, 80 and 100\% of crop evapotranspiration, respectively. Different letters within columns indicates that there are significant differences at 0.05 level of probability

Table 3 Influence of silicon form and irrigation regime on iron (Fe), zinc ( $\mathrm{Zn})$, manganese (Mn), and silicon (Si) content in wheat plants in 2019/20 (S1) and 2020/21 (S2) seasons

\begin{tabular}{|c|c|c|c|c|c|c|c|c|}
\hline \multirow[t]{2}{*}{ Variable } & \multicolumn{2}{|c|}{$\mathrm{Fe}\left(\mathrm{mg} \mathrm{kg}^{-1}\right)$} & \multicolumn{2}{|c|}{$\mathrm{Zn}\left(\mathrm{mg} \mathrm{kg}^{-1}\right)$} & \multicolumn{2}{|c|}{$\operatorname{Mn}\left(\mathrm{mg} \mathrm{kg}^{-1}\right)$} & \multicolumn{2}{|c|}{ Si $\left(\mathrm{mg} \mathrm{kg}^{-1}\right)$} \\
\hline & S1 & S2 & $\mathrm{S} 1$ & $\mathrm{~S} 2$ & S1 & $\mathrm{S} 2$ & S1 & S2 \\
\hline \multicolumn{9}{|l|}{ Silicon form } \\
\hline Potassium silicate & $71.9 \mathrm{a}$ & $54.7 \mathrm{a}$ & $91.9 \mathrm{~b}$ & $130.0 \mathrm{~d}$ & $28.2 \mathrm{ab}$ & $35.2 \mathrm{c}$ & $0.54 \mathrm{c}$ & $0.37 \mathrm{~b}$ \\
\hline Calcium silicate & $131.4 \mathrm{a}$ & $92.4 \mathrm{a}$ & $76.9 \mathrm{c}$ & $131.2 \mathrm{c}$ & $23.7 \mathrm{bc}$ & $41.2 b$ & $0.73 b$ & $0.83 \mathrm{a}$ \\
\hline Aluminum silicate & $83.4 \mathrm{a}$ & $53.4 \mathrm{a}$ & $60.7 \mathrm{~d}$ & $140.8 b$ & $18.9 \mathrm{c}$ & $46.8 \mathrm{a}$ & $0.81 \mathrm{a}$ & $0.76 \mathrm{a}$ \\
\hline Control & $134.4 \mathrm{a}$ & $107.2 \mathrm{a}$ & $97.7 \mathrm{a}$ & $153.4 \mathrm{a}$ & $29.9 \mathrm{a}$ & $51.5 \mathrm{a}$ & $0.34 \mathrm{~d}$ & $0.32 b$ \\
\hline \multicolumn{9}{|l|}{ Irrigation regime } \\
\hline Irr60 & $122.8 \mathrm{a}$ & $76.6 \mathrm{a}$ & $99.9 \mathrm{a}$ & $156.5 \mathrm{a}$ & $30.6 \mathrm{a}$ & $55.4 \mathrm{a}$ & $0.50 \mathrm{c}$ & $0.51 b$ \\
\hline Irr80 & $107.5 \mathrm{a}$ & $80.0 \mathrm{a}$ & $71.3 \mathrm{c}$ & $118.8 \mathrm{c}$ & $22.9 \mathrm{~b}$ & $32.7 \mathrm{a}$ & $0.59 b$ & $0.61 \mathrm{a}$ \\
\hline Irr100 & $85.4 \mathrm{a}$ & 73.9a & $74.1 \mathrm{~b}$ & $141.3 \mathrm{~b}$ & $22.0 \mathrm{~b}$ & $42.9 \mathrm{a}$ & $0.73 a$ & $0.58 \mathrm{a}$ \\
\hline
\end{tabular}

Irr60, Irr80 and Irr100: irrigation at 60, 80 and 100\% of crop evapotranspiration, respectively. Different letters within columns indicates that there are significant differences at 0.05 level of probability

The interaction between irrigation regime and silicon form had significant effects only on $\mathrm{Mn}$ and $\mathrm{Si}$ content in wheat plants (Table 4). Irr60 $\times$ potassium silicate and Irr80 $\times$ control showed the maximum Mn values in 2019/20 season. In 2020/21 season, Irr60 $\times$ calcium silicate, aluminum silicate or control as well as Irr $100 \times$ aluminum silicate or control recorded the highest $\mathrm{Mn}$ content. Irr $100 \times$ calcium silicate (in the first season) as well as Irr60 or Irr $80 \times$ calcium silicate and Irr $100 \times$ aluminum silicate (in the second season) were the distinctive combinations for increasing Si content in wheat plants.

\section{Crop Parameters}

All wheat crop traits significantly influenced by $\mathrm{Si}$ form in both growing seasons, except spike length (Table 5). Generally, noticeable enhancements in crop traits were obtained owing to spraying Si forms compared to the control. In this context, potassium silicate achieved the maximum values. However, in 2019/20 season, SPAD value (with calcium silicate or aluminum silicate) and grains weight spike ${ }^{-1}$ (with calcium silicate) statistically leveled that of potassium silicate. Also, the differences between potassium silicate, calcium silicate, and aluminum silicate were not significant for SPAD value, grains weight spike ${ }^{-1}$, weight of 1000 grains, and grain yield ha- in 2020/21 season.

Irrigation regime had remarkable impacts on all crop traits in both seasons (Table 5). Along the two seasons, Irr100 was the effective treatment for enhancing SPAD value, spike length, grains weight spike ${ }^{-1}$, weight of 1000 grains, and grain yield ha ${ }^{-1}$. Spike length of Irr80 was similar to that of Irr100 in 2020/21 season.

The statistical analysis revealed that spike length, weight of 1000 grains, and grain yield ha ${ }^{-1}$ significantly responded to the interaction between $\mathrm{Si}$ form and irrigation regime in both seasons (Table 6). Commonly, silicate forms were more efficient for increasing spike length, weight of 1000 grains, and grain yield $\mathrm{ha}^{-1}$ under well-watered plants (Irr100). Reducing irrigation water by $20 \%$ (Irr80) than Irr100 caused reductions in grain yield by $8.2,13.1,10.6 \%$ in the first season and $12.5,17.4,14.3 \%$ in the second sea- 
Table 4 Influence of irrigation regime and silicon form interaction on manganese (Mn), and silicon (Si) content in wheat plants in 2019/20 (S1) and 2020/21 (S2) seasons

\begin{tabular}{|c|c|c|c|c|c|}
\hline \multicolumn{2}{|c|}{ Variable } & \multicolumn{2}{|c|}{$\mathrm{Mn}\left(\mathrm{mg} \mathrm{kg}^{-1}\right)$} & \multicolumn{2}{|c|}{$\mathrm{Si}\left(\mathrm{mg} \mathrm{kg}^{-1}\right)$} \\
\hline & & $\overline{S 1}$ & $\mathrm{~S} 2$ & $\overline{S 1}$ & S2 \\
\hline \multirow[t]{4}{*}{ Irr60 } & Potassium silicate & $45.6 \mathrm{a}$ & $34.3 \mathrm{de}$ & 0.241 & $0.40 \mathrm{ef}$ \\
\hline & Calcium silicate & $27.5 \mathrm{~cd}$ & $65.8 \mathrm{a}$ & $0.33 \mathrm{j}$ & $0.88 \mathrm{abc}$ \\
\hline & Aluminum silicate & $27.5 \mathrm{~cd}$ & $58.8 \mathrm{a}$ & $1.02 \mathrm{~b}$ & $0.32 \mathrm{ef}$ \\
\hline & Control & $21.6 \mathrm{cde}$ & $62.7 \mathrm{a}$ & $0.40 \mathrm{~h}$ & $0.47 \mathrm{de}$ \\
\hline \multirow[t]{4}{*}{ Irr80 } & Potassium silicate & $20.5 \mathrm{de}$ & $35.7 \mathrm{cde}$ & $0.86 \mathrm{~d}$ & $0.43 \mathrm{def}$ \\
\hline & Calcium silicate & $13.3 \mathrm{e}$ & $28.3 \mathrm{de}$ & $0.79 \mathrm{e}$ & $0.96 \mathrm{ab}$ \\
\hline & Aluminum silicate & $16.6 \mathrm{e}$ & $25.3 \mathrm{e}$ & $0.46 \mathrm{~g}$ & $0.84 \mathrm{bc}$ \\
\hline & Control & $37.8 \mathrm{ab}$ & $41.5 \mathrm{bcd}$ & $0.26 \mathrm{k}$ & $0.22 \mathrm{f}$ \\
\hline \multirow[t]{4}{*}{ Irr100 } & Potassium silicate & $18.5 \mathrm{de}$ & $35.6 \mathrm{cde}$ & $0.53 \mathrm{f}$ & $0.29 \mathrm{ef}$ \\
\hline & Calcium silicate & $30.3 b c$ & $29.4 \mathrm{de}$ & $1.06 \mathrm{a}$ & $0.66 \mathrm{~cd}$ \\
\hline & Aluminum silicate & $12.6 \mathrm{e}$ & $56.4 \mathrm{ab}$ & $0.96 \mathrm{c}$ & $1.10 \mathrm{a}$ \\
\hline & Control & $30.3 b c$ & $50.4 \mathrm{abc}$ & $0.36 \mathrm{i}$ & $0.26 \mathrm{ef}$ \\
\hline
\end{tabular}

Irr60, Irr80 and Irr100: irrigation at 60, 80 and 100\% of crop evapotranspiration, respectively. Different letters within columns indicates that there are significant differences at 0.05 level of probability

Table 5 Influence of silicon form and irrigation regime on agronomic traits of wheat in 2019/20 (S1) and 2020/21 (S2) seasons

\begin{tabular}{|c|c|c|c|c|c|c|c|c|c|c|}
\hline \multirow[t]{2}{*}{ Variable } & \multicolumn{2}{|c|}{$\begin{array}{l}\text { Leaf greenness (SPAD } \\
\text { value) }\end{array}$} & \multicolumn{2}{|c|}{ Spike length $(\mathrm{cm})$} & \multicolumn{2}{|c|}{$\begin{array}{l}\text { Grains weight spike }{ }^{-1} \\
(\mathrm{~g})\end{array}$} & \multicolumn{2}{|c|}{$\begin{array}{l}\text { Weight of } 1000 \text { grains } \\
(\mathrm{g})\end{array}$} & \multicolumn{2}{|c|}{ Grain yield $\left(\mathrm{t} \mathrm{ha}^{-1}\right)$} \\
\hline & $\overline{\mathrm{S} 1}$ & $\mathrm{~S} 2$ & $\overline{\mathrm{S} 1}$ & S2 & $\overline{\text { S1 }}$ & $\mathrm{S} 2$ & $\overline{\mathrm{S} 1}$ & S2 & $\bar{S} 1$ & S2 \\
\hline \multicolumn{11}{|l|}{ Silicon form } \\
\hline $\begin{array}{l}\text { Potassium } \\
\text { silicate }\end{array}$ & $44.0 \mathrm{a}$ & $39.3 \mathrm{a}$ & $10.1 \mathrm{a}$ & $10.1 \mathrm{a}$ & $2.02 \mathrm{a}$ & $2.06 \mathrm{a}$ & $44.6 \mathrm{a}$ & $45.3 \mathrm{a}$ & $5.69 \mathrm{a}$ & $5.98 \mathrm{a}$ \\
\hline $\begin{array}{l}\text { Calcium } \\
\text { silicate }\end{array}$ & $43.6 a b$ & $39.6 \mathrm{a}$ & $10.2 \mathrm{a}$ & $10.1 \mathrm{a}$ & $1.96 \mathrm{~b}$ & $2.02 \mathrm{ab}$ & $43.7 \mathrm{c}$ & $44.8 \mathrm{a}$ & $5.53 \mathrm{~b}$ & $5.82 \mathrm{a}$ \\
\hline $\begin{array}{l}\text { Aluminum } \\
\text { silicate }\end{array}$ & $43.5 \mathrm{ab}$ & $38.7 \mathrm{a}$ & $10.2 \mathrm{a}$ & $10.2 \mathrm{a}$ & $1.99 \mathrm{ab}$ & $2.02 \mathrm{ab}$ & $44.1 \mathrm{~b}$ & $45.0 \mathrm{a}$ & $5.59 \mathrm{~b}$ & $5.91 \mathrm{a}$ \\
\hline Control & $42.9 \mathrm{~b}$ & $38.4 \mathrm{~b}$ & $10.1 \mathrm{a}$ & $10.0 \mathrm{a}$ & $1.93 \mathrm{c}$ & $1.96 \mathrm{~b}$ & $42.8 \mathrm{~d}$ & $43.7 \mathrm{~b}$ & $5.41 \mathrm{c}$ & $5.77 \mathrm{~b}$ \\
\hline \multicolumn{11}{|c|}{ Irrigation regime } \\
\hline Irr60 & $39.8 \mathrm{c}$ & $37.5 \mathrm{c}$ & $9.8 \mathrm{c}$ & $9.6 \mathrm{~b}$ & $1.66 \mathrm{c}$ & $1.74 \mathrm{c}$ & $39.0 \mathrm{c}$ & $40.5 \mathrm{c}$ & $4.32 \mathrm{c}$ & $4.55 \mathrm{c}$ \\
\hline Irr80 & $44.0 \mathrm{~b}$ & $39.2 b$ & $10.2 b$ & $10.3 \mathrm{a}$ & $2.02 b$ & $2.01 \mathrm{~b}$ & $45.3 b$ & $44.3 b$ & $5.82 \mathrm{~b}$ & $5.98 \mathrm{~b}$ \\
\hline Irr100 & $46.7 \mathrm{a}$ & $40.3 \mathrm{a}$ & $10.5 \mathrm{a}$ & $10.3 \mathrm{a}$ & $2.24 \mathrm{a}$ & $2.30 \mathrm{a}$ & $47.0 \mathrm{a}$ & $49.3 \mathrm{a}$ & $6.52 \mathrm{a}$ & $7.08 \mathrm{a}$ \\
\hline
\end{tabular}

Irr60, Irr80 and Irr100: irrigation at 60, 80 and 100\% of crop evapotranspiration, respectively. Different letters within columns indicates that there are significant differences at 0.05 level of probability

son with application of potassium silicate, calcium silicate and aluminum silicate, respectively.

\section{Discussion}

There is no doubt that the nutrients balance within plants is substantially correlated with water status of plant cells. In this regard, it has been reported that deficit irrigation reduces plant growth by affecting various physiological and biochemical processes, such as photosynthesis, respiration, translocation, ion uptake, carbohydrates, nutrient metabolism, and growth promoters (Farooq et al. 2008; Razmjoo et al. 2008; Salem et al. 2021). Also, reducing water supply caused severe depression in plant physio- logical, anatomical, and agronomic traits (El-Bially et al. 2018; El-Metwally et al. 2021; Makhlouf et al. 2022). In the stressed plants accumulation of abscisic acid is stimulated in leaves, which sets up ionic imbalance that compels potassium ion $\left(\mathrm{K}^{+}\right)$to leak out from guard cells and loss of guard cell turgor pressure. Thus, narrowing the aperture mostly would be due to reduced leaf relative water content and increased stomatal closure (Abd El-Mageed et al. 2021; Makhlouf et al. 2022). Water deficit reduced the concentration of $\mathrm{N}$ and $\mathrm{P}$ in plant tissue (He and Dijkstra 2014) and decreased nutrient uptake from soil (Ge et al. 2012; Sardans and Peñuelas 2012). Decreases in nutrient uptake during drought could be attributed to the reduction of nutrient supply through mineralization process (Sanaullah et al. 2012; Saudy et al. 2020), and by reducing nutrient diffusion 
Table 6 Influence of irrigation regime and silicon form interaction on agronomic traits of wheat in 2019/20 (S1) and 2020/21 (S2) seasons

\begin{tabular}{|c|c|c|c|c|c|c|c|}
\hline \multicolumn{2}{|c|}{ Variable } & \multicolumn{2}{|c|}{ Spike length $(\mathrm{cm})$} & \multicolumn{2}{|c|}{ Weight of 1000 grains $(\mathrm{g})$} & \multicolumn{2}{|c|}{ Grain yield $\left(\mathrm{t} \mathrm{ha}^{-1}\right)$} \\
\hline$\overline{\text { Irr60 }}$ & Potassium silicate & $\begin{array}{l}\text { S1 } \\
9.9 \mathrm{~d}\end{array}$ & $\begin{array}{l}\text { S2 } \\
9.7 \mathrm{abc}\end{array}$ & $\begin{array}{l}\mathrm{S} 1 \\
39.8 \mathrm{f}\end{array}$ & $\begin{array}{l}\mathrm{S} 2 \\
41.1 \mathrm{de}\end{array}$ & $\begin{array}{l}\mathrm{S} 1 \\
4.45 \mathrm{f}\end{array}$ & $\frac{S 2}{4.60 c}$ \\
\hline & Calcium silicate & $9.6 \mathrm{e}$ & $9.3 \mathrm{c}$ & $38.9 \mathrm{~g}$ & 41.0de & $4.29 \mathrm{~g}$ & $4.44 \mathrm{c}$ \\
\hline & Aluminum silicate & $9.7 \mathrm{e}$ & $9.5 \mathrm{bc}$ & $39.0 \mathrm{~g}$ & $40.3 \mathrm{e}$ & $4.32 \mathrm{~g}$ & $4.54 \mathrm{c}$ \\
\hline & Control & $10.0 \mathrm{~cd}$ & 9.9abc & $38.4 \mathrm{~h}$ & $39.8 \mathrm{e}$ & $4.24 \mathrm{~g}$ & $4.62 \mathrm{c}$ \\
\hline \multirow[t]{4}{*}{ Irr80 } & Potassium silicate & $10.2 \mathrm{bc}$ & $10.4 \mathrm{a}$ & $46.5 b$ & $44.2 \mathrm{bcd}$ & $6.04 \mathrm{c}$ & $6.22 b$ \\
\hline & Calcium silicate & $10.3 b$ & $10.5 \mathrm{a}$ & $44.8 \mathrm{~d}$ & $44.3 \mathrm{bcd}$ & $5.72 \mathrm{e}$ & $5.89 \mathrm{~b}$ \\
\hline & Aluminum silicate & $10.2 \mathrm{bc}$ & $10.3 \mathrm{ab}$ & $45.9 \mathrm{c}$ & $45.3 \mathrm{bc}$ & $5.88 \mathrm{~d}$ & $6.09 \mathrm{~b}$ \\
\hline & Control & $10.1 \mathrm{bcd}$ & $10.0 \mathrm{abc}$ & $44.1 \mathrm{e}$ & $43.4 \mathrm{cde}$ & $5.64 \mathrm{e}$ & $5.72 b$ \\
\hline \multirow[t]{4}{*}{ Irr100 } & Potassium silicate & $10.2 \mathrm{bc}$ & $10.1 \mathrm{abc}$ & $47.5 \mathrm{a}$ & $50.7 \mathrm{a}$ & $6.58 \mathrm{a}$ & $7.11 \mathrm{a}$ \\
\hline & Calcium silicate & $10.7 \mathrm{a}$ & $10.4 \mathrm{a}$ & $47.4 \mathrm{a}$ & $49.2 \mathrm{a}$ & $6.58 \mathrm{a}$ & $7.13 \mathrm{a}$ \\
\hline & Aluminum silicate & $10.7 \mathrm{a}$ & $10.6 \mathrm{a}$ & $47.4 \mathrm{a}$ & $49.4 \mathrm{a}$ & $6.58 \mathrm{a}$ & $7.11 \mathrm{a}$ \\
\hline & Control & $10.2 b c$ & $10.3 \mathrm{ab}$ & $45.9 \mathrm{c}$ & $47.9 \mathrm{ab}$ & $6.35 b$ & $6.96 a$ \\
\hline
\end{tabular}

Irr60, Irr80 and Irr100: irrigation at 60, 80 and 100\% of crop evapotranspiration, respectively. Different letters within columns indicates that there are significant differences at 0.05 level of probability

and mass flow in the soil (Lambers et al. 2008). Disturbing the kinetics of nutrient under drought could decrease nutrient uptake by plant roots (Christophe et al. 2011). On the contrast, our results showed that macronutrients concentration did not affect by low water supply (Table 2). Since the impact of drought depends on its intensity and duration during a plant's life cycle (Bradford and Hsiao 1982), irrigating wheat by 60 or $80 \%$ of crop evapotranspiration could not represent a significant issue for macronutrient uptake. However, Si concentration was the pronounced element that drastically reduced with water deficit (Table 4). Reductions in Si concentration with Irr60 were 31.5 and $13.7 \%$ in the first and second seasons, respectively.

Drought not only affects the plant nutrient balance but also plant growth and development. In this respect, the revealed results in Table 5 clarified that all yield traits were reduced with lowering water supply. As averages of the two seasons, the reductions owing to Irr60 and Irr80 compared to Irr100 were 11.1 and $4.4 \%$ in SPAD value, 6.7 and $1.4 \%$ in spike length, 25.1 and $11.2 \%$ in grains weight spike ${ }^{-1}$, 17.4 and $7.0 \%$ in weight of 1000 grains, as well as 34.8 and $13.2 \%$ in grain yield ha ${ }^{-1}$, respectively (Fig. 1). Under deficit irrigation at $80 \%$ of crop evapotranspiration, the growth and yield index of spring wheat were not influenced greatly and reached 5-13\% lower than under full irrigation. While, under deficit irrigation at $60 \%$ crop evapotranspiration, the growth and yield index were greatly reduced by about $10-37 \%$ lower than under full irrigation (Zhou 2020). Water stress occurred decreases in water uptake by roots, leaf expansion and stomatal conductance, causing a decrease in carbon assimilation in photosynthesis process and yield (Christophe et al. 2011; Sharma et al. 2020a; El-Metwally and Saudy 2021). Declined frequency of cell division and cell enlargement, root differentiation, shoot

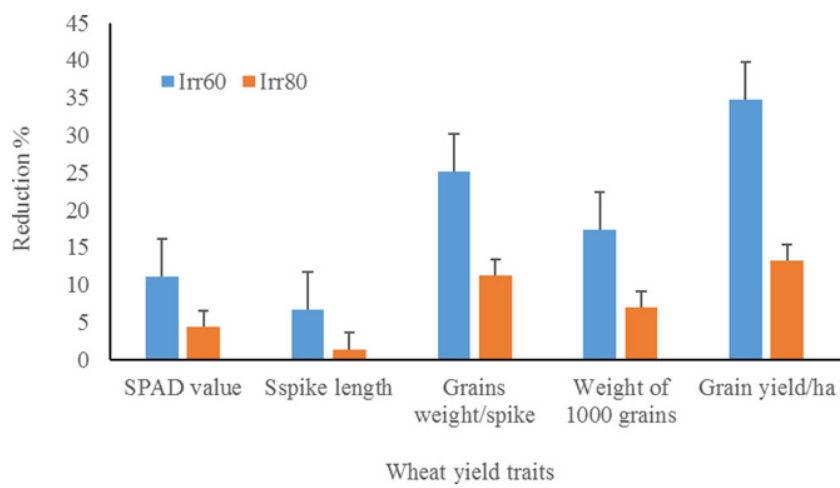

Fig. 1 Reductions in leaf greenness (SPAD value), spike length (cm), grains weight spike ${ }^{-1}(\mathrm{~g})$ weight of 1000 grains $(\mathrm{g})$, and grain yield $\left(\mathrm{t} \mathrm{ha} \mathrm{a}^{-1}\right)$ of wheat owing to Irr60 and Irr80 compared to full irrigation (Irr100). Irr60, Irr80 and Irr100: irrigation at 60, 80 and 100\% of crop evapotranspiration, respectively

length, altered stomatal movements, water and mineral nutrition association with decreased plant yield and water use efficiency are the major outcomes of drought (Kumawat and Sharma 2018; Mubarak et al. 2021). Photosynthesis activity is decreased primarily by closing of stomata, membrane injury and altered functioning of several enzymes, particularly those which are associated with ATP synthesis (Kumawat and Sharma 2018; Sharma et al. 2020a). Drought stress conditions also enhanced generation of reactive oxygen species (ROS) and reactive nitrogen species (RNS), which disturb the cell redox regulatory functioning (Laxa et al. 2019; Sharma et al. 2020b). Accordingly, water deficit, especially at elongation and heading stages would reduce the yield of wheat (Tari 2016).

To mitigate against the detrimental impacts of water deficit, new tactics are urgently needed to ensure future food security. Results of the current study showed the ben- 
eficial effect of Si in enhancing leaf greenness (Table 5). Improvements in SPAD or chlorophyll content were noted with silicate fertilizer (Silva et al. 2012; Radkowski and Radkowska 2018). Moreover, Si fertilization had the potentiality to improve plant tolerance to drought (Debona et al. 2017; Luyckx et al. 2017). In this situation, Si can improve anti-oxidative both enzymatic and non-enzymatic defense mechanisms thus, avoid damage from ROS produced by various abiotic stresses (Maghsoudi et al. 2019; Sattar et al. 2019). Si influences water relations in droughttreated plants, since it induces the formation of a silica cuticle double layer under the leaf epidermis which reduces water losses through cuticular transpiration (Gong et al. 2003). Si also reduces stomatal conductance in relation to turgor loss of guard cells resulting from Si deposition and modified cell wall properties (Zhu and Gong 2014). The improvement of drought resistance due to $\mathrm{Si}$ application could be ascribed to its strong abilities to extract water from the soil because of Si-related promotion of root elongation (Hattori et al. 2005) and up-regulation of aquaporin genes (Liu et al. 2015). Si has been described to reduce many of the effects including the biological and abiotic stresses of plants at high evaporation rates, and maintain the water potential of plants, photosynthesis, stomatal conductivity, and leaf erection (Das et al. 2017). Si improves the plant growth by modulating the nutrient $(\mathrm{Na}, \mathrm{Mg}$ and Si) uptake and phytohormone levels and alleviating plant stress levels (Gong et al. 2008). Enhancing the tolerance of the wheat plants against drought stress was achieved, since Si caused balance of endogenous hormones (Xu et al. 2017). Moreover, the associated cation with silicon could has a promotive role for enhancing drought tolerance. In this respect, osmotic adjustment is considered an effective component of drought resistance (Gomathi et al. 2010). Potassium affects the osmotic adjustment of the plant and increases drought resistance by enhancing the translocation of assimilates and maintaining osmotic charge (Marschner 1995; Mubarak et al. 2016). Accordingly, supplying wheat plants by potassium silicate, particularly under severe water deficit is regarded as a crucial action to enhance the tolerance of plants with reducing yield losses.

\section{Conclusion}

Since lower accumulation of $\mathrm{Si}$ in plant tissues under water deficit than well-watered was recorded, the significance of foliar application of $\mathrm{Si}$ when plants receive low water supply become more essential. Moreover, potassium, calcium, and aluminum silicates showing similar yield, farmers could choose any available Si form to fertilize wheat irrigated by water less than the full irrigation. However, under moderate water supply (irrigation by $80 \%$ of crop evapotranspi- ration), potassium silicate could be the favorite $\mathrm{Si}$ form for obtaining better yield.

Funding This research was supported by the Faculty of Agriculture, Ain Shams University and Desert Research Centre, Egypt.

Funding Open access funding provided by The Science, Technology \& Innovation Funding Authority (STDF) in cooperation with The Egyptian Knowledge Bank (EKB).

Conflict of interest E.M. M. Salem, M.K. M. Kenawey, H.S. Saudy and M. Mubarak declare that they have no competing interests.

Open Access This article is licensed under a Creative Commons Attribution 4.0 International License, which permits use, sharing, adaptation, distribution and reproduction in any medium or format, as long as you give appropriate credit to the original author(s) and the source, provide a link to the Creative Commons licence, and indicate if changes were made. The images or other third party material in this article are included in the article's Creative Commons licence, unless indicated otherwise in a credit line to the material. If material is not included in the article's Creative Commons licence and your intended use is not permitted by statutory regulation or exceeds the permitted use, you will need to obtain permission directly from the copyright holder. To view a copy of this licence, visit http://creativecommons.org/licenses/by/4. $0 /$

\section{References}

Abd El-Mageed TA, Belal EE, Rady MOA, Abd El-Mageed SA, Mansour E, Awad MF, Semida WM (2021) Acidified biochar as a soil amendment to drought stressed (Vicia faba L.) plants: Influences on growth and productivity, nutrient status, and water use efficiency. Agronomy 11:1290. https://doi.org/10.3390/ agronomy 11071290

Abd-Elrahman SH, Saudy HS, Abd El-Fattah DA, Hashem FA (2022) Effect of irrigation water and organic fertilizer on reducing nitrate accumulation and boosting lettuce productivity. J Soil Sci Plant Nutr. In Press

Abdel-Haliem MEF, Hegazy HS, Hassan NS, Naguib DM (2017) Effect of silica ions and nano silica on rice plants under salinity stress. Ecol Eng 99:282-289

Abu-Muriefah SS (2015) Effect of sitosterol on growth, metabolism, and protein pattern of pepper (Capsicum annum L) plants grown under salt stress conditions. Int J Agric Sci 8:94-106

Allen RG, Pereira LS, Raes D, Smith M (1998) Crop evapotranspiration-guidelines for computing crop water requirements. FAO irrigation and drainage paper, vol Rome. FAO, Italy

Benton J Jr (2001) Laboratory guide for conducting soil test and plant analysis. CRC Press, Boca Raton, London, New York, Washington, D.C.

Bradford KJ, Hsiao TC (1982) Physiological responses to moderate water stress. In: Lange OL, Nobel PS, Osmond CB, Ziegler H (eds) Physiological plant ecology. Springer, Berlin, pp 263-324

Casella G (2008) Statistical design, 1st edn. Springer, Gainesville

Chapman HD, Pratt PF (1961) Methods of analysis for soils, plants and waters. Division of Agric Sci, Berkeley Univ, California, pp $150-152$

Christophe S, Jean-Christophe A, Annabelle L, Alain O, Marion P, Anne-Sophie V (2011) Plant N fluxes and modulation by nitrogen, heat and water stresses: a review based on comparison of legumes and non-legume plants. In: Shanker A, Venkateswarlu B (eds) Abiotic stress in plants - mechanisms and adaptations. InTech, Rijeka, pp 79-118

Das KK, Swamy GS, Biswas D, Chnaniya KK (2017) The response of soil application of diatomaceous earth as a source of silicon 
on leaf nutrient status of guava. Int J Curr Microbiol App Sci 6:1394-1399

Debona D, Rodrigues FA, Datnoff LE (2017) Silicon's role in abiotic and biotic plant stresses. Ann Rev Phytopathol 55:85-107. https:// doi.org/10.1146/annurev-phyto-080516-035312

Dorrenbos J, Pruitt WO (1977) Crop water requirements. FAO irrigation and drainage paper, vol 24. FAO, Rome

El-Bially MA, Saudy HS, El-Metwally IM, Shahin MG (2018) Efficacy of ascorbic acid as a cofactor for alleviating water deficit impacts and enhancing sunflower yield and irrigation water-use efficiency. Agric Water Manag 208:132-139. https://doi.org/10. 1016/j.agwat.2018.06.016

El-Metwally IM, Saudy HS (2021) Interactional impacts of drought and weed stresses on nutritional status of seeds and water use efficiency of peanut plants grown in arid conditions. Gesunde Pflanz. https://doi.org/10.1007/s10343-021-00557-3

El-Metwally IM, Saudy HS, Abdelhamid MT (2021) Efficacy of benzyladenine for compensating the reduction in soybean productivity under low water supply. Ital J Agrometeorol 2:81-90. https:// doi.org/10.36253/ijam-872

El-Metwally IM, Geries L, Saudy HS (2022) Interactive effect of soil mulching and irrigation regime on yield, irrigation water use efficiency and weeds of trickle-irrigated onion. Arch Agron Soil Sci. https://doi.org/10.1080/03650340.2020.1869723

Etesami H, Ryong Jeong B (2018) Review and future prospects on the action mechanisms in alleviating biotic and abiotic stresses in plants. Ecotoxicol Environ Saf 147:881-896

Farooq M, Basra SMA, Wahid A, Cheema ZA, Cheema MA, Khaliq A (2008) Physiological role of exogenously applied glycinebetaine in improving drought tolerance of fine grain aromatic rice (Oryza sativa L.). J Agric Crop Sci 194:325-333. https://doi.org/10.1111/ j.1439-037X.2008.00323.x

Ge TD, Sun NB, Bai LP, Tong CL, Sui FG (2012) Effects of drought stress on phosphorus and potassium uptake dynamics in summer maize (Zea mays) throughout the growth cycle. Acta Physiol Plant 34:2179-2186

Gomathi R, Vasantha S, Thandapani V (2010) Mechanism of osmo regulation in response to salinity stress in sugarcane. Sugar Technol $12: 305-311$

Gong HJ, Chen KM, Chen GC, Wang SM, Zhang CL (2003) Effects of silicon on growth of wheat under drought. J Plant Nutr 26:1055-1063. https://doi.org/10.1081/PLN-120020075

Gong HJ, Chen KM, Zhao ZG, Chen GC, Zhou W (2008) Effects of silicon on defense of wheat against oxidative stress under drought at different developmental stages. Biol Plant 52:592-596

Hattori T, Inanaga S, Araki H, An P, Morita S, Luxová M, Lus A (2005) Application of silicon enhanced drought tolerance in sorghum bicolor. Physiol Plant 123:459-466. https://doi.org/10.1111/j.13993054.2005.00481.x

He M, Dijkstra FA (2014) Drought effect on plant nitrogen and phosphorus: a meta-analysis. New Phytol 204:924-931

Iqbal MA, Junaid R, Wajid N, Sabry H, Yassir K, Ayman S (2021) Rainfed winter wheat (Triticum aestivum L.) cultivars respond differently to integrated fertilization in Pakistan. Fresenius Environ Bull 30:3115-3121

IUSS Working Group WRB (2015) World reference base for soil resources 2014, update 2015 international soil classification system for naming soils and creating legends for soil maps. World soil resources reports, vol 106. FAO, Rome

Kizilgeci F, Yildirim M, Islam MS, Ratnasekera D, Iqbal MA, Sabagh AE (2021) Normalized difference vegetation index and chlorophyll content for precision nitrogen management in durum wheat cultivars under semi-arid conditions. Sustainability 13:3725. https://doi.org/10.3390/su13073725

Kumawat KR, Sharma NK (2018) Effect of drought stress on plants growth. Pop Kheti 6:239-241

Lambers H, Chapin FS, Pons TL (2008) Plant physiological ecology. Springer, New York
Laxa M, Liebthal M, Telman W, Chibani K, Dietz K-J (2019) The role of the plant antioxidant system in drought tolerance. Antioxidants 8:94

Liu P, Yin L, Wang S, Zhang M, Deng X, Zhang S, Tanaka K (2015) Enhanced root hydraulic conductance by aquaporin regulation accounts for silicon alleviated salt-induced osmotic stress in sorghum bicolor L. Environ Exp Bot 111:42-51. https://doi.org/ 10.1016/j.envexpbot.2014.10.006

Luyckx M, Hausman J-F, Lutts S, Guerriero G (2017) Silicon and plants: current knowledge and technological perspectives. Front Plant Sci 8:411. https://doi.org/10.3389/fpls.2017.00411

Maghsoudi K, Emam Y, Ashraf M, Arvin MJ (2019) Alleviation of field water stress in wheat cultivars by using silicon and salicylic acid applied separately or in combination. Crop Pasture Sci 70:36-43. https://doi.org/10.1071/CP18213

Makhlouf BSI, Soha KRA, Saudy HS (2022) Efficacy of humic acids and chitosan for enhancing yield and sugar quality of sugar beet under moderate and severe drought. J Soil Sci Plant Nutr. https:// doi.org/10.1007/s42729-022-00762-7

Marschner H (1995) Mineral nutrition of higher plants, 2nd edn. Academic Press, San Diego

Mecfel J, Hinke S, Goedel WA, Marx G, Fehlhaber R, Bäucker E, Wienhaus O (2007) Effect of silicon fertilizers on silicon accumulation in wheat. J Plant Nutr Soil Sci 170:769-772. https://doi. org/10.1002/jpln.200625038

Meena KK, Sorty AM, Bitla UM, Choudhary K, Gupta P, Pareek A, Singh DP, Prabha R, Sahu PK, Gupta VK, Singh HB, Krishanani KK, Minhas PS (2017) Abiotic stress responses and microbe-mediated mitigation in plants: the Omics strategies. Front Plant Sci 8:172. https://doi.org/10.3389/fpls.2017.00172

Merriam JL, Shearer MN, Burt CM (1983) Evaluating irrigation systems and practices. Chapter 17. In: Jensen ME (ed) Design and operation of farm irrigation systems. ASAE monograph, vol 3

Ming D, Pei Z, Naeem M, Gong H, Weijun Z (2012) Silicon alleviates PEG-induced water-deficit stress in upland Rice seedlings by enhancing osmotic adjustment. J Agron Crop Sci 198:14-26. https:// doi.org/10.1111/j.1439-037X.2011.00486.x

Mubarak M, Salem EMM, Kenawey MKM, Saudy HS (2021) Changes in calcareous soil activity, nutrient availability, and corn productivity due to the integrated effect of straw mulch and irrigation regimes. J Soil Sci Plant Nutr 21:2020-2031. https://doi.org/10. 1007/s42729-021-00498-w

Mubarak MU, Zahir M, Ahmad S, Wakeel A (2016) Sugar beet yield and industrial sugar contents improved by potassium fertilization under scarce and adequate moisture conditions. J Integr Agric 15:2620-2626

Radkowski A, Radkowska I (2018) Effects of silicate fertilizer on seed yield in timothy-grass (Phleum pratense L.). Ecol Chem Eng $\mathrm{S}$ 25:169-180. https://doi.org/10.1515/Eces-2018-0012

Razmjoo K, Heydarizadeh P, Sabzalian MR (2008) Effect of salinity and drought stresses on growth parameters and essential oil content of Matricaria chamomile. Int J Agric Biol 10:451-454

Rodrigues FA, Resende RS, Dallagnol LJ, Datnoff LE (2015) Silicon potentiates host defense mechanisms against infection by plant pathogens. In: Rodrigues FA, Datnoff LE (eds) Silicon and plant diseases. Springer, Zurich, pp 109-130

Salem EMM, Kenawey MKM, Saudy HS, Mubarak M (2021) Soil mulching and deficit irrigation effect on sustainability of nutrients availability and uptake, and productivity of maize grown in calcareous soils. Commun Soil Sci Plant Anal 52:1745-1761. https:// doi.org/10.1080/00103624.2021.1892733

Salim BB (2014) Effect of boron and silicon on alleviating salt stress in maize. Middle East J Agric Res 3:1196-1204

Sanaullah M, Rumpel C, Charrier X, Chabbi A (2012) How does drought stress influence the decomposition of plant litter with contrasting quality in a grassland ecosystem? Plant Soil 352:277-288 
Sardans J, Peñuelas J (2012) The role of plants in the effects of global change on nutrient availability and stoichiometry in the plant-soil system. Plant Physiol 160:1741-1761

Sattar A, Cheema MA, Sher A, Ijaz M, Ul-Allah S, Nawaz A, Abbas T, Ali Q (2019) Physiological and biochemical attributes of bread wheat (Triticum aestivum L.) seedlings are influenced by foliar application of silicon and selenium under water deficit. Acta Physiol Plant 41:146. https://doi.org/10.1007/s11738-019-29382

Saudy HS, El-Metwally IM (2019) Nutrient utilization indices of NPK and drought management in groundnut under sandy soil conditions. Commun Soil Sci Plant Anal 50:1821-1828. https://doi.org/ 10.1080/00103624.2019.1635147

Saudy HS, Mubarak M (2015) Mitigating the detrimental impacts of nitrogen deficit and fenoxaprop-p-ethyl herbicide on wheat using silicon. Commun Soil Sci Plant Anal 46:913-923

Saudy HS, El-Metwally IM, Abd El-Samad GA (2020) Physio-biochemical and nutrient constituents of peanut plants under bentazone herbicide for broad-leaved weed control and water regimes in dry land areas. J Arid Land 12:630-639. https://doi.org/10. 1007/s40333-020-0020-y

Saudy HS, El-Bially M, El-Metwally IM, Shahin MG (2021) Physiobiochemical and agronomic response of ascorbic acid treated sunflower (Helianthus Annuus) grown at different sowing dates and under various irrigation regimes. Gesunde Pflanz 73:169-179. https://doi.org/10.1007/s10343-020-00535-1

Sharma A, Kumar V, Shahzad B, Ramakrishnan M, Sidhu GPS, Bali AS, Handa N, Kapoor D, Yadav P, Khanna K (2020a) Photosynthetic response of plants under different abiotic stresses: a review. J Plant Growth Regul 39:509-531

Sharma A, Wang J, Xu D, Tao S, Chong S, Yan D, Li Z, Yuan H, Zheng B (2020b) Melatonin regulates the functional components of photosynthesis, antioxidant system, gene expression, and metabolic pathways to induce drought resistance in grafted Carya cathayensis plants. Sci Total Environ 713:136675

Shewry PR, Hey SJ (2015) The contribution of wheat to human diet and health. Food Energy Secur 4:178-202

Silva ON, Lobato AKS, Avila FW, Costa RLC, Oliveira Neto CF, Santos Filho BG, Martins Filho AM, Lemos R, Pinho JM, Medeiros MBCL, Cardoso MS, Andrade IP (2012) Silicon induced increase in chlorophyll is modulated by the leaf water potential in two water-deficient tomato cultivars. Plant Soil Environ 58:481-486

Süß A, Danner M, Obster C, Locherer M, Hank T, Richter K (2015) Measuring leaf chlorophyll content with the Konica Minolta SPAD-502plus-theory, measurement, problems, interpretation. EnMAP field guides technical report, GFZ data services. https:// doi.org/10.2312/enmap.2015.010

Tari AF (2016) The effects of different deficit irrigation strategies on yield, quality, and water-use efficiencies of wheat under semi-arid conditions. Agric Water Manag 167:1-10

Watanabe FC, Olsen SR (1965) Test of an ascorbic acid method for determining phosphorus in water and $\mathrm{NaHCO}_{3}$ extracts from soils. Soil Sci Soc Am Proc 29:677-678

Xu L, Islam F, Ali B, Pei Z, Li J, Ghani MA, Zhou W (2017) Silicon water-deficit stress differentially modulate physiology and ultrastructure in wheat (Triticum aestivum L.). 3 Biotech 7:273. https://doi.org/10.1007/s13205-017-0904-5

Yadav S, Modi P, Dave A, Vijapura A, Patel D, Patel M (2020) Effect of abiotic stress on crops. In: Hasanuzzaman M (ed) Sust Crop Prod. Intech Open, London https://doi.org/10.5772/intechopen.88434

Ye M, Song Y, Long J, Wang R, Baerson SR, Pan Z (2013) Priming of jasmonate-mediated antiherbivore defense responses in rice by silicon. Proc Natl Acad Sci 110:3631-3639

Zhou L (2020) Influences of deficit irrigation on soil water content distribution and spring wheat growth in Hetao Irrigation District, Inner Mongolia of China. Water Supply 20:3722-3729. https:// doi.org/10.2166/ws.2020.155

Zhu Y, Gong H (2014) Beneficial effects of silicon on salt and drought tolerance in plants. Agron Sustain Dev 34:455-472. https://doi. org/10.1007/s13593-013-0194-1

Hani Saber Saudy (PhD) was born in Giza, Egypt, in 1973. He is Professor of Agronomy Department, Faculty of Agriculture, Ain Shams University, Egypt. He is a specialist in Field Crop Production (Crop Physiology and Management). His specific research has focused on the Weed Ecology \& Management. And he is interested in abiotic stress issues in agriculture. 